Vesna TOMOVSKA

UDK: 821.124-6.09

821.14'02-21.09

Original research paper

\title{
THE OVID'S FEMALE LETTER MISSING FROM EURIPIDES’ TRAGEDY
}

\begin{abstract}
This writing is an analysis of an epistolary poem (4.) from the collection "Heroides" by Ovid and of the tragedy "Hippolytus" by Euripides. The connection between these two poetic forms can be made on the basis of the mythological tradition regarding the content. However, what enables a deeper and broader hermeneutic analysis is the possibility to connect them in terms of their structure and intertwine them into a unique poetic form. Name$l y$, regardless of the intentio auctoris, this female letter by Ovid has an intertextual potential to become part of Euripides' female play in a certain form of a pre-play. Furthermore, this meta collaboration between two poetic forms from different cultural provenances has the capacity to generate intergeneric similarities and dependences enabled by the letter, as a hybrid or unifying genre.
\end{abstract}

Key words: FEMALE LETTER, EPISTOLARY POEM, "HEROIDES", OVID, "HIPPOLYTUS", EURIPIDES

Ovid's female letter, which is the subject matter of this essay, is part of the collection Heroides ${ }^{1}$ (The Heroines). This collection can be contextualized in different ways and in different fields, fiction and non-fiction, starting from those that refer to the author himself and reaching to those beyond his personal opus, beyond his field of action, beyond the historical time and space. In Ovid's poetics, the collection of elegies

\footnotetext{
${ }^{1}$ The first edition of this collection, compiled at the same time with the collection Amores (c. 15 $\mathrm{BC}$ ), included poems-letters by female mythological characters addressed to their lovers or husbands. Appropriate to the mythological provenience of the epistolary subjects, in the company of which Sappho also appears, obviously because of the phantasmagorical personality of her addressee Phaon and their mythologized love, this edition was titled Heroides (The Heroines) with a familiar Greek form for female gender, by analogy to the original form for male gender heros, ois, $\mathrm{m}$.

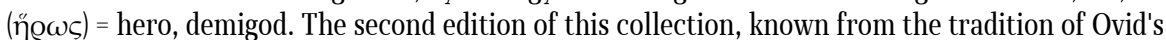
texts, was supplemented with several epistolary poems, answers to the addressed heroes (Paris to Helen, Leandar to Hero and Acontius to Cydippe), which presented the collection with three additional epistolary communications, along with the fifteen one-way addresses. So, the original title, considered inappropriate and inaccurate (because the epistolary subjects were not only heroines, but there were heroes, as well), was changed to Epistuale (Letters), as Ovid himself calls them (Ars amat. 3.345).
} 
Heroides has the position of a focus that connects his other literary products of different genre provenience and, hence, of various contextualization capacities. Therefore, the poems in this collection, with regards to Love as the basic literary motif, are thematically akin to the collections: Amores, Ars amatoria (The Art of Love) and Remedia amoris (Remedy of Love); due to the mythological frame in which the literary matter is being tackled, the collection Heroides is, in fact, an externalized part of the mythopoetic Metamorphoses; ${ }^{2}$ with regards to the literary form, these love letters, along with the Epistulae ex Ponto (Letters from the Black Sea), cover the epistolary literary corpus of Ovid, while with regards to his pronounced gender homogenization of the epistolary subject, these female letters and female script (female discourse) are linked, based upon literature, with the isolated and probably unfinished long poem Medicamina Faciei Femineae (Women's Facial Cosmetics). ${ }^{3}$ The literary relations of the collection Heroides with the other literary products in Ovid's opus are mapping the contextual fields which can include the hermeneutic tendencies in reading (studying) these poems. The markers of those fields would be: mythology, love poetry, literary letter (epistle) and female discourse. Beyond Ovid's literary commitment, beyond the Roman literary and cultural circles, the same markers could designate the contexts of some of Euripides's plays, in this case the tragedies Medea and Hippolytus together with the letters of Medea (Her. 12) and Phaedra (Her. 4) from the collection Heroides form metarelations of proto-patterns for the semantic and formative structures.

1.

In $2 \mathrm{BC}$, in his didactic collection Ars armatoria (3.345-6), ${ }^{4}$ Ovid states that his previously published Letters (sc. Heroides) are "a work not known (before) to the other" Roman poets. This qualification of the poetic innovativeness of the love letters by the Heroines can only be partially relevant, provided it primarily refers only to the Roman literature and exclusively to love poetry. This is because, neither the letter, as a communication product, nor the epistle, as a literary form, were unknown to Rome, even less to Hellada. In other words, from the literary position he had earned in the last two

${ }^{2}$ Compare Heroides 12 (Medea to Iason) and Metamorphoses 7.1-424.

${ }^{3}$ This poem shows a certain literary activism of Ovid in which he realizes his published project (Ars amat. 3.101-128) on the comprehensive celebration and fulfilment of the Care (Cultus) aimed towards complete urbanization of Rome and its definite release from the century-long dependence of the value mark of a "big village". Compare Horatius, Epist. 2.1.156-7: Graecia capta ferum victorem cepit et artis|intulit agresti Latio. (Captive Greece captured, in turn, her uncivilised) Conquerors, and brought the arts to rustic Latium.)

${ }^{4}$ In these elegies Ovid addresses both men (Books 1 and 2) and women (Book3) and teaches them the art of love recommending, among other things, carefully chosen readings. Along with the works of Callimachus, Tibullus, Sappho, Menander quite instructive for improving the love strategies, according to the Poet, are his collections Amores and Epistola, which should be read „softly with sweetly-teachable lips“ (docili molliter ore ... composita voce) [Ars amat. 3.344-5]. 
decades of the old age, when he wrote the Letters of the mythological lovers, Ovid could perceive the century-long history of the Hellenic and Roman epistolary tradition both as an epistolographic practice and as an epistolary literary form.

In the lyric collection The Heroines there are literary influences of different cultural and genre proveniences. The lyric letter can incidentally be found with Lucilius and Catullus, while Horatius, the senior contemporary of Ovid, was the first to make a collection of poetic letters titled Epistulae (Letters). Horatius saw in the literary letter an opportunity for a close(r) communication of the author with his audience ${ }^{5}$ and a chance for a looser distribution of his attitudes. The literary letter embraces and uses this particular aspect of the letter as a communication tool in a hidden form, available to only one addressee or to a few involved in the epistolary communication, to publish a content that is marked with exclusivity. It is probably not by chance that the letter, as a medium of discursive communication, is stereotypically related to the woman as an epistolary subject due to its ability to reveal and concurrently protect the personal, the hidden, the inner. ${ }^{6}$ So, the epistolary typologization which is gender founded according to the dominant topic, results in the conclusion that men write official letters, on serious and socially important issues, while women write private letters. This "public privacy" is the very aspect of the letter, approved by the tradition and recommended as an appropriate literary form, which Ovid used in order to revive the mythological stories in accordance with Rome to which he proudly belonged. ${ }^{8}$

The epistolary discursive strategies directly proceed from the oration practice and the rhetoric skills and didactics. The period when Ovid is literary active is a period of an exceptionally rich epistolary production documented in numerous epistolary collections of different epistolary genres, fiction and non-fiction, poetry and prose. ${ }^{9}$ The popularity of the letter as a form of literary provocation is probably due to the increasing influence of the rhetoric on art, especially the declamation as a compulsory fabricated oration that was used for mastering and exercising the rhetoric skill through simulation. The collection of lyrical letters Heroides reveal the mastered rhetoric skill of Ovid on many levels. First of all, through the very choice of the epistolary subject, in this case female, which is a radically innovative practice in the antique literature, used to reveal her love story and, by that, activate a traditional rhetoric practice of $\eta \theta$ o

\footnotetext{
${ }^{5}$ See Taplin, Oliver (ed.), p.122.

${ }^{6}$ History of letter writing begins with a female letter that was written by Atossa, queen of the Persians. See Rosenmeyer 2001, p. 25, 28, 49.

${ }^{7}$ The gender marked polarisation of the space Home-City, Private-Public as a Female-Male opposition is an influential model for generating all kinds of social positions and cultural products of Ancient World.

${ }^{8}$ Ars amat. 3.121-2: Prisca iuvent alios: ego me nunc denique natum|Gratulor: haec aetas moribus apta meis. (Others may delight in ancient times: I congratulate myself| on having been born just now: this age suits my nature.)

${ }^{9}$ See Novaković 1982.
} 
$i \alpha$ (= poetics of the character, portraying). ${ }^{10}$ Ovid also invests his knowledge of the rhetoric skill in structuring the literary letter as a discursive form meant to fill the basic purpose of every speech, to incite influence and change with the addressee.

Besides the rhetoric, the Letters of the mythological lovers have their literary etiology in the tradition of the Roman play, more precisely in Plautus's comedy that is, basically, a remake of the Hellenistic new attic comedy, which for its part, takes inspiration from Euripides's tragedy. In these plays, the letter is not an independent literary form, but a certain dramatic, or more precisely, stage device, but with an important purpose and influence on the dramatic storyline. Most often, the contents of the letter are not part of the dramatic text, but a reason for the dramatic plot where the epistolary communication, that is, the epistolary reception, generates anagnorisis (recognizing). Ovid's Love Letters, whose content is marked with dramatics, as independent poetic forms are, in a way, epistolary plays, inner dialogues ${ }^{11}$ of the heroines with their addressees, written in some disturbing moments for them. Actually, the letters were written by women that address the absent lover (either due to unrequited love, physical absence or due to leaving the romantic relationship) which meets the basic constitutive precondition for an epistolary communication, ${ }^{12}$ while presenting the epistolary poem with an element of literary credibility.

2.

The letters of Medea and Phaedra in Ovid's collection Heroides, in different ways, literarily communicate with the appropriate tragedies, Hippolytus and Medea by Euripides. The Letter of Phaedra can easily be seen as a structural element of the tragedy Hippolytus because it is already included in the dramatic text, yet not as an extensive epistolary narration, but as an epistolary prop or as a, so called, stage letter. ${ }^{13}$ Ovid was undoubtedly, familiar with this literary tradition and this particular dramatic situation which are often referred to in Phaedra's epistle. When, at the very beginning, the epistolary subject (Phaedra) addresses the addressee (Hippolytus) and persuades him to read

\footnotetext{
${ }^{10}$ Compare Sen. Contr. 2.2.12.1: Declamabat autem Naso raro controversias et non nisi ethicas; libentius dicebat suasorias: molesta illi erat omnis argumentatio. (Ovid rarely gave declamations on controversies, and they were always of ethical (character) variety. He was happier to declaim suasoriae (persuasion speeches). He hated to adduce proofs of any kind.)

${ }^{11}$ Demetrius: On Style 227: "The letter, like the dialogue, should abound in glimpses of character. It may be said that everybody reveals his own soul in his letters. In every other form of composition it is possible to discern the writer's character, but in none so clearly as in the epistolary."

${ }^{12}$ Trapp, 1: "(...)the need for a letter as a medium of communication normally arises because the two parties are physically distant (separated) from each other, and so they are unable to communicate by unmediated voice or gesture."

${ }^{13}$ Rosenmeyer 2001, p.63: „Like theatrical devices, letters were introduced presumably to liven up a scene, to support an argument with a visual aid, or to impart critical information (...) it is a device for bringing a past event onto stage in narrative rather than in acted form."
} 
the letter she intends to write, she encourages him to do so despite the tradition known in tragedy according to which reading letters can be dangerous, even deadly. This emphasis of the risk of epistolary reception is a kind of a footnote in the text of Ovid's letter that links him to his own protohistory in a different literary text, the one of Euripides's tragedy.

When Euripides wrote his tragedy Hippolytus, he used the story from the mythological tradition where, normally, there was no epistle, as a basis. It is known that Euripides wrote and showed two versions of that play. In the first version, Phaedra orally reveals to Hippolytus her passion for him. This play was not well received, the audience thought that this explicit behavior of Phaedra goes beyond the boundaries of the usual women's modesty. The Introduction to the antique editions of the second version of the tragedy explains that Euripides reworked the play in order to remove the contents that the audience found offensive in the first version. So, in the second version of this tragedy, the one known to tradition, Phaedra kills herself making it impossible for her to reveal her love passion directly and orally to Hippolytus. But, for the purpose of the dramatic plot, it was necessary to find a literary means to be used by Phaedra when telling Theseus the reason for her death and blaming Hippolytus for that. So, in the second version of the play Euripides included the letter which became the key dramatic element. Letters have the capacity of making the voice of the one that is absent and that is the author of the writing present. In this case, with the letter she wrote, Phaedra remained permanently present, although already physically permanently absent. The written words, inscribed on the tablets that hang on her dead hand, are a replacement of the live voice and, according to the nature of the writing; they affect Theseus even harder than the orally uttered words would do. In circumstances when the author is permanently gone, the written content acquires permanent value lacking the possibility of any changes. So, Hippolytus cannot say anything in his defense that would convince Theseus of his innocence. Theseus does not read the letter aloud, but with his reaction he informs the audience of its contents, ${ }^{14}$ which leads to the tragic end of the play. With that letter, Phaedra protects her reputation and at the same time secures revenge, while Theseus punishes his son with horrible death.

3.

Four centuries after the performance of the tragedy Hippolytus in Athens, Ovid wrote in Rome the letter of Phaedra to Hippolytus as a substitute of the orally revealed passion from the first version of Euripides's play. This poetic letter differs from the other epistles in the collection Heroides because, unlike all the other epistolary subjects who are abandoned women, Phaedra was not abandoned by her lover, but is in search of him. She wrote her love letter in order to conquer her addressee, that is, to

${ }^{14}$ Euripides, Hippolytus 877-80: The tablet cries aloud, it cries things grievous. How shall I escape from the weight of my misfortunes? For I am utterly undone, such is the tune I in my wretchedness have heard sung by the tablet! 
persuade him to accept her revealed love. To that task, the author of the letter, Ovid, responds with a certain rhetoric strategy, activating the standard practices of influencing and changing the addressee's opinion.

Phaedra's letter has a familiar structure of a speech formatted by the agenda for devising a convincing discursive form. Phaedra starts the letter indirectly, from a distance and enigmatically, presenting herself in third person like The girl from Crete (Cressa puella), and she refers to the addressee Hippolytus as the man (born) of an Amazon woman (Amazonius vir); thus, besides the origin, she also defines the desired relation (vir - puella) and her reason for writing the letter. In rhetorical context, Phaedra/Ovid in the introduction (exordium) [1-6] maps out the task of discursive persuasion in this letter. As expected, what follows is narration (narratio) [7-16], the part developing the circumstances that precede the act of persuasion. Phaedra tells that she'd hesitated for a long time whether to reveal her feelings or to remain silent. However, she decided to speak through a letter, inspired and encouraged, persuaded by the power of Love (Amor) which is here personified as a very powerful deity whose force even the gods cannot resist, something that reigns over everything and everyone. Phaedra addresses this deity directly, asking him to help her light the fire in the one who is senseless. In the invocation to Amor we can recognize the traditional address of the Poet to the Muse where Phaedra's letter is supposed to open the central and most important part of the persuasive discourse, the argumentation (argumentatio) [17-164]. In this case, Ovid devises several argumentative practices based on different persuasive tools: those that refer to the epistolary subject ( $\tilde{\eta} \theta \mathrm{os})$, those that are generated in the logical structur-

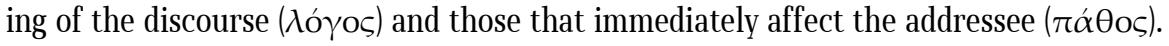
Most of the argumentation is dedicated to creating an idea of one's own character, citing the glorious origin of Phaedra, "as far as Helios" [156-164]. Phaedra contextualizes her love passion as "the fate of her own family": her grandmother Europa was seduced by Jupiter disguised as a bull, her mother Pasiphae fell in love with the bull sent down by Neptune and gave birth to the monster Minotaur, "her sin and her burden", and her sister Ariadne helped the stranger Theseus in killing Minotaur and escaped with him. Her love for Hippolytus, that she now reveals, can also be added to this line of "unconventional love experiences in the family". [53-66] Phaedra's attempt to objectify the circumstances related to Theseus that, in a way, recommend this relationship even on the level of alliance and revenge, is a key part of the argumentation. She reminds that Theseus offended her and his son by leaving them and going to his friend Pirithous; she blames him for killing Minotaur and for leaving Ariadne, with which he offended her, and for killing Antiope the Amazon, Hippolytus's mother, with which he offended his own son. [105-128]

In the description of Phaedra's love, we can recognize an echo of Plato's Phaedrus when she reveals how her love for Hippolytus affects the reconsideration of her behavior and arouses interest for different practices: respecting Diana more than the other deities, going hunting, driving a chariot. In her confession she admits that she 
feels possessed by some deity, so she compares herself to the enthusiastic worshippers of Bacchus and Cybele. [37-52]

Part of the argumentation is based on the stereotypical dichotomy of the goddesses Diana and Venus which is, actually, the foundation upon which Euripides structures his play Hippolytus. Phaedra recommends their reconciliation in the religious practice of Hippolytus and reminds of several paradigms from the mythological tradition (Cephalus, Adonis and Meleager) which activates one of the most powerful tools of the persuasive discourse, the example. [85-104]

In the conclusion (conclusio) of Phaedra's letter, she addresses Hippolytus directly asking him to "open his heart" and not be "feistier than the wild bull defeated by her mother Pasiphae". [165-176] In a prayer she celebrates Venus, but also the deities worshiped by Hippolytus: Diana, Faun, Pan, the Nymphs. In the last lines Phaedra tries to influence Hippolytus's decision to return her love $\mathrm{e}^{15}$ by activating the most powerful

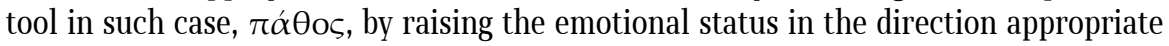
to the aim of persuasion. [165-176]

\section{4.}

If we disregard the historical frames of the literary production of Euripides's tragedy Hippolytus and the Letter of Phaedra in Ovid's collection Heroides, these two poetic forms could meet, on some meta level, within a common work. This joining would be justified by the possibility to fill a crack in the text of the play that stares with the enigmaticness of the unrevealed contents of the "silent letter". The Letter of Phaedra, same as the other one-way letters in the collection Heroides, contains confessions and resembles to fragments of an intimate diary. In accordance with the Roman literary context, Ovid in his Letters radicalizes Euripides's intention to show the characters (in the play) as revealing their personal and intimate experiences, so he opts for the letter as a format that is, by definition, meant for the other, for externalization or objectification of the personal, the intimate. The extensiveness of the letter and the narratological character make it an appropriate replacement for the standard scenes with the messenger in the plays having the function of revealing details from behind the scene, from the inside of the home or the temple, from areas that are inaccessible for the audience to observe.

${ }^{15}$ Ovidius, Heroides 4. 175-6:

Addimus his precibus lacrimas quoque; verba precantis

qui legis, et lacrimas finge videre meas!

(I add to these prayers my tears as well. The words of the one who prays

You read; imagine you see my tears also.) 


\section{References}

Fulkerson, Laurel. (2005). The Ovidian Heroine as Author, Reading, Writing and Community in the Heroides. Cambridge: Cambridge University Press.

Lindheim, Sara H. (2003). Male and Female, Epistolary Narrative and Desire in Ovid's Heroides. The University of Wisconsin Press.

Novaković, Darko. (1982). "Fabularni oblici u antičkoj epistolografiji". Latina et Graeca 20, pp. 69-85.

Rosenmeyer, Patricia A. (2001). Ancient Epistolary Fictions. Cambridge: Cambridge University Press.

Rosenmeyer, Patricia A. (2006). Ancient Greek Literary Letters. London and New York: Routledge.

Taplin, Oliver, ed. (2000). Literature in the Roman World. Oxford: Oxford University Press.

Trapp, Michael, ed. (2003). Greek and Latin Letters, An Anthology with Translation. Cambridge: Cambridge University Press. 